B. CTAHOIII

\title{
ФОРМАЛЬНЫЕ ТЕОРИИ ОБЪЕМА И СОДЕРЖАНИЯ ВЫРАЖЕНИЙ
}

\author{
(P е 3 ю м е)
}

В статье представлена попытка систематизачии формальнологических понятиевых конструкций, при помощи которых в современной семантике разрешается задача экспликации традиционных понятий ебъема (денотация, экстенсионал) и содержания (значение, конотация, интенсионал) выражений. В § 1 дана общая характеристика схемы теоретической процедуры обыкновенно применяемой с этой целью, а в $\S \S 2-4$ представлены детально очередные этапы этой процедуры. примерами послужили конструкции Р. КАРнАпА содержащиеся в его теории эктенсионала и интенсионала а также построенные частично на подобие этой теории концепци Р. С ушки ия Е. В. БетА. Представлены различия между концепщиями этих авторов. Указаны также дальнейшие возможности модификации этих конщепций в рамках общей им системы теоретической процедуры. 